\title{
Hezekiah and the Assyrian tribute
}

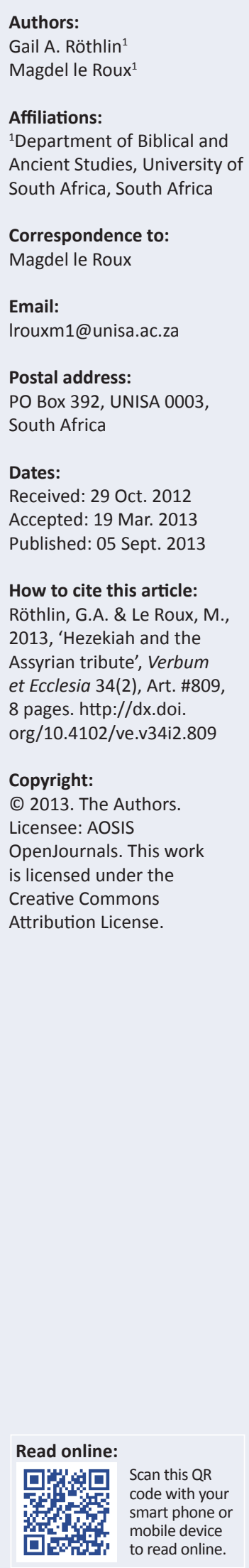

The immensity of Hezekiah's tribute payment to the Assyrian monarch, Sennacherib (2 Ki 18:14) has elicited limited reflection by scholars. Agriculture, generally believed to have formed the basis of the Judaean economy, could not alone have financed Hezekiah's expenditure at the close of the 8th and the beginning of the 7th century BCE. Alternative sources of revenue, in addition to the income from the tithes and taxes as a result of his religious reforms, which undoubtedly contributed substantially, must have been available to the king. Archaeological data will not enable us to prove the veracity of the biblical narratives, but they will help us to interpret it, illuminate the context of the biblical passages and provide valuable information for the reconstruction of the social and cultural history of the early Israelites. An entirely accurate picture of the actual events that occurred will continue to elude us.

\section{Introduction}

And the king of Assyria appointed unto Hezekiah king of Judah three hundred talents of silver and thirty talents of gold (2 Ki 18:14). ${ }^{1}$

This seemingly insignificant detail has, as Becking (2007:269) rightly points out, prompted very few theologians and historians to reflect on the immensity of Hezekiah's payment to Sennacherib; it is simply taken for granted. Even more surprising is the fact that so few scholars question Hezekiah's ability to meet this extraordinarily high tribute payment, or question how the Judaean king acquired such wealth to meet Sennacherib's demands. The whys and wherefores of the Assyrian campaign against Judah in 701 BCE tend to take pride of place with the majority of scholars (Holladay 2006:311-331). ${ }^{2}$ In addition, this payment should also be seen in the context of Hezekiah's other considerable expenditures, ${ }^{3}$ such as the costs involved to (Blakely \& Hardin 2002):

- fortify all the Judaean cities, including Jerusalem (2 Chr 32:5)

- $\quad$ secure his capital's water source (2 Ki 20:20) and to stock her armoury (2 Chr 32:5)

- build barns, stalls and sheepfolds to store the bountiful tithes of agricultural products and livestock (2 Chr 32:28)

- campaign against the Philistines and regain the territory down to Gaza (2 Ki 16:8) that the Philistines had taken following the Syro-Ephraimitic War (p. 52).

The Judaean economy and the economic history of 'ancient Israel't have been largely neglected by scholars probably due to data constraints and an almost complete lack of epigraphic sources (Buchholz 1988:393). The Bible, traditionally our oldest and 'primary' source of textual information on the history of 'ancient Israel', is a religious document (as we know) with the political history and theological ideology of the Israelites its main focus. The Bible was not intended to communicate information on the economy of the country, nor was it meant to be subject to economic analysis (Buchholz 1988:393). Le Roux (1998:477) argues that there is not even a 'minimum' left of Israel's past. We have lost the 'quid' of history forever and there is no way of retrieving what has been lost. Historical reason is a latecomer to the scene and is only confronted with traces of the past.

Answers to questions surrounding issues such as the systems of exchange, the organisation of trade, the role of the elite in commerce and production, the role and status of traders, price fluctuations, to mention but a few, continue to elude researchers. In the attempt to identify the possible source, or sources of Hezekiah's revenue, we have based our argument on a survey of the textual and archaeological evidence currently available (cf. Röthlin 2009:1-10).

1.The New Jerusalem Bible (NjB) has been quoted throughout this study.

2.John S. Holladay is an exception; see his 'Hezekiah's tribute, long-distance trade, and the wealth of nations ca. 1000-600 BC: A new perspective' (Holladay 2006:311-331).

3.We are aware of the possibility that some of the building activities attributed to Hezekiah might be attributed to the longer reign of Manasseh (approx. 695-642 BCE) and transferred to Hezekiah in accordance to both kings' image in the Hebrew Bible, but for the purpose of this article, it will not be discussed here.

4.It is not within the scope of this article to deal with the issue at stake surrounding the existence of the 'state of Israel'. It is an extremely complex and hotly debated issue, particularly in our contemporary world (cf. Grabbe 1997:12). 
The books of Kings and Chronicles present two different accounts of the Hezekiah narrative. Most scholars agree that the books of Chronicles can be 'typified as historiography', but the features that contribute 'to this book being categorised as historiography are often defined differently by different scholars (see e.g. essays in Graham et al [1997])' (Jonker 2012:340). The same problem exists with the book of Kings. The authors of the two different books were obviously not objective and had their own political and theological ideology in mind. Mitchell (2007:18.7) indicates that the Chronicler used the power of genre to transform the given in the source texts (mainly in Kings) in his creation of another genre (in Jonker 2012:342). Jonker (2007:24-25) says 'that the Books of Chronicles are simultaneously an attempt to reformulate and sanitize the older traditions about the past ...' ${ }^{5}$ It is clear that the subjectivity of the biblical scholar will influence interpretation and the evaluation of the source material.

Archaeology, or the science of material culture, involves the recovery, study and interpretation of the material remains of the past. Whereas the Biblical narratives are mainly the product of the upper social levels, the archaeological evidence has the potential to illuminate all levels, particularly the lower echelons. The biblical narrators were extremely selective about what they recorded; archaeology is sometimes capable of supplementing the information they either lacked or failed to include (Röthlin 2009:10). Nevertheless, it should be remembered that an entirely accurate picture of the actual events that occurred will continue to elude us (Röthlin 2009:5). Archaeological data will not enable us to prove the veracity of the Bible; they will only assist us to interpret it, illuminate the context of the biblical passages and provide valuable information for the reconstruction of the social and cultural history of the early Israelites. The results of archaeology have shown that there are instances where the Bible and archaeology do converge, suggesting that traces of history or a historical 'core' to the Bible does exist, as this study of Hezekiah shows. The subjectivity of the archaeologist will ultimately influence the interpretation and evaluation of the source material, as well as the historian's final reconstruction of the course of events (Ahlström 1991:117; cf. Le Roux 1998:483). In the same way that a responsible reconstruction of the historical events that surround Hezekiah cannot be based purely on the biblical texts, so neither can it be based solely on the archaeological record: archaeology too has its limitations.

The discovery of the Royal Assyrian annals made a huge contribution towards our understanding of this period under discussion. The annals first made their appearance during the reign of Tiglath-Pileser I (1114-1076 BCE). Written in Akkadian on clay tablets, barrels and cylinders often buried in the foundations of buildings or inscribed on stone wall reliefs and stele, they documented in detailed, chronological sequence the building projects and military campaigns undertaken by the king (Van de Mieroop 2007:180). Kings went into battle firmly believing they were fulfilling a

5.This debate does not fall within the parameters of this discussion. commission from their national deity Ashur. The annals, inscribed after the battles to inform Ashur of the outcome of the task entrusted to them, were extremely biased and hugely propagandistic (Wiseman 1993:40). Although seemingly (and understandably) Assyrian-biased, they greatly augment the biblical texts (Miller \& Hayes 1986:221).

A table has been compiled reflecting the tributes received by numerous Assyrian kings from 890-669 BCE based on the information available from the Assyrian annals and the Summary inscriptions. ${ }^{6}$ It is far from comprehensive as it only features the absolute amounts taken from the textual sources, but it provides interesting insight into the magnitude of Judah's payment in relation to payments by other kings and/or countries.

After considering Judah's possible financial situation when Hezekiah ascended the Judaean throne, we discuss the plausible sources of revenue which might have contributed to Hezekiah's income.

\section{Hezekiah's tribute payment in context}

'Three hundred talents of silver and thirty talents of gold' (2 Ki 18:14) would have been a substantial quantity of precious metals even in the late 18 th to early 17 th century BCE.

Within the Assyrian Royal inscriptions Hezekiah's tribute to Sennacherib was one of the largest tributes ever received by a monarch, as becomes clear from the survey made by Bär (1996:29-56). Only Metenna of Tyre and Mati'il of Arpad paid higher tributes to Tiglath-Pileser II (Holladay 2006:325). Judah, along with Mati'il of Arpad, paid the third largest amount of gold and the eighth largest amount of silver demanded during this period. Noteworthy is the fact that the majority of the countries that rendered greater quantities of precious metal were situated at strategic locations to benefit from the trade passing through the area. Table 1 lists the tribute payments demanded by eight Assyrian monarchs over two centuries. In the annals, silver usually appears before gold.

\section{Judah's financial situation when Hezekiah ascended the throne}

According to the narrative in 2 Kings, in 734 BCE Hezekiah's father Ahaz had stripped the Temple of all its silver and gold, and sent it along with all the gold and silver from the palace treasury to Tiglath-Pileser III as 'a present' (2 Ki 16:9) for Assyrian assistance against Rezin of Damascus and Pekah of Israel (2 Ki 16:8-9). There is no mention of further 'annual' payments or any indication that these might have taken place. The royal Assyrian inscriptions also refer to only one payment made by 'Iaukhazi [Jehoahaz] matu Iauda-ai'

6.The sources are listed in the table. Due to space constraints in the table ARAB will denote Ancient Records of Assyria and Babylonia by Luckenbill (1968). 
TABLE 1: Judah's tribute payment in relation to the payments by other countries or kings.

\begin{tabular}{|c|c|c|c|c|c|c|c|c|c|}
\hline Country or City or King & $\begin{array}{l}\text { Assyrian } \\
\text { monarch }\end{array}$ & $\begin{array}{l}\text { Gold } \dagger \text { in talents } \\
\text { and minas }\end{array}$ & kg & Silver in talents and mina & kg & $\begin{array}{l}\text { Lead in } \\
\text { talents }\end{array}$ & $\begin{array}{l}\text { Copper in } \\
\text { talents }\end{array}$ & $\begin{array}{l}\text { Iron in } \\
\text { talents }\end{array}$ & Reference \\
\hline Suhi-Iluibni & TU II & $20 \mathrm{~m}$ & 10 & $3 t$ & 90 & - & - & - & $A R A B \mid: 130$ \\
\hline Halupe - Sûru & TU ॥ & $20 m$ & 10 & $20 m$ & 10 & 32 & 130 & 1 & $A R A B \mid: 131$ \\
\hline Hुindānu & TU ॥ & $10 m$ & 5 & $10 \mathrm{~m}$ & 5 & 2 & - & - & $A R A B \mid: 130$ \\
\hline Sirku - Issin-Dada & TU ॥ & $3 \mathrm{~m}$ & 1.5 & $7 \mathrm{~m}$ & 35 & - & - & - & $A R A B \mid: 130$ \\
\hline Laqû >Harâni & TU II & $3 \mathrm{~m}$ & 1.5 & $17 m$ & 8.5 & 6 & - & - & $A R A B \mid: 130$ \\
\hline Laqû < Hamath & TU ॥ & - & - & $10 \mathrm{~m}$ & 5 & - & - & - & $A R A B \mid: 131$ \\
\hline Bit-Zamâni & ANP & $2 \mathrm{t}(60 \mathrm{~kg})$ & 61 & $2 \mathrm{t}(60 \mathrm{~kg})$ & 66.5 & 100 & $100 \S$ & 300 & $A R A B \mid: 157$ \\
\hline Bit-Zamâni - Ilânut & ANP & $2 \mathrm{~m}(1 \mathrm{~kg})$ & 61 & $13 \mathrm{~m}(6.5 \mathrm{~kg})$ & 66.5 & 100 & $100 \S$ & 300 & $A R A B \mid: 181$ \\
\hline Hattina - Lubarna & ANP & $1 \mathrm{t}$ & 30 & $20 t$ & 600 & 100 & - & 100 & $A R A B \mid: 165$ \\
\hline Carchemish - Sangara & S III & - & - & $20 t$ & 600 & - & 100 & 250 & $A R A B \mid: 165$ \\
\hline Carchemish - Sangara & SIII & $3 t$ & 90 & $70 t$ & 210 & - & 30 & 100 & $A R A B \mid: 217$ \\
\hline Hatti & SIII & $3 t$ & 90 & $100 \mathrm{t}$ & 900 & - & 300 & 100 & $A R A B \mid: 217$ \\
\hline Bit-Agûsi - Aramu & SIII & $10 m$ & 5 & $6 \mathrm{t}$ & 180 & - & - & - & $A R A B \mid: 217$ \\
\hline Damascus - Mari & TP III & $20 t$ & 600 & $2300 \mathrm{t}$ & 69000 & - & 3000 & 5000 & $A R A B \mid: 263$ \\
\hline Tyre-Metenna & TP III & $150 \mathrm{t} \Phi$ & 4500 & $2000 \mathrm{t}$ & 60000 & - & - & - & ARAB I:288; Summ 7:16' \\
\hline (Bit-Agûsi) Arpad - Mati'ilu & TP III & $30 \mathrm{t}$ & 900 & $2000 t$ & 60000 & - & - & - & Summ 9:24' \\
\hline Tyre - Hiram & TP III & $20 \mathrm{t}$ & - & - & - & - & - & - & Summ 9:7' rev \\
\hline Unqi & TP III & $20 t$ & - & - & - & - & - & - & Summ 9:26' \\
\hline Israel - Hoshea & TP III & $10 \mathrm{t}$ & - & $x$ & - & - & - & - & ARAB I:293; Summ 4:18' \\
\hline Kardunias (Babylonia) $\dagger \uparrow$ & TP III & $10 t$ & - & $1000 \mathrm{t}$ & 30000 & - & - & - & $A R A B \mid: 270$ \\
\hline Tabal - Hullî & TP III & $10 \mathrm{t}$ & - & $1000 \mathrm{t}$ & 30000 & - & - & - & 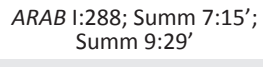 \\
\hline Damascus - Rezin & TP III & $3 t$ & - & - & - & - & - & - & $A R A B \| I: 274$ \\
\hline Gaza - Hanunu & TP III & $x$ & - & $800 \mathrm{t}$ & 24000 & - & - & - & Summ $8: 15^{\prime}+4$ \\
\hline Musasir - Urzana (temple) & SII & Approx. $7 \mathrm{t}=210 \mathrm{~kg}$ & 1239 & $162 \mathrm{t} \& 20 \mathrm{~m}-3 / 36=5879 \mathrm{~kg}$ & 9881 & - & - & - & $A R A B \| I: 109$ \\
\hline Musasir (treasury) & SII & $34 \mathrm{t} \& 18 \mathrm{~m}=1029 \mathrm{~kg}$ & 1239 & $167 \mathrm{t} \& 2.5 \mathrm{~m}=5011 \mathrm{~kg}$ & 9881 & - & - & - & $A R A B \|: 110$ \\
\hline Carchemish - Pisiris (booty) & SII & $11 \mathrm{t} \& 30 \mathrm{~m}$ & 345 & $2100 t \& 24 m$ & 63012 & - & - & - & $A R A B \|: 73$ \\
\hline Judah - Hezekiah & SB & $30 t$ & 900 & $800 \mathrm{t}$ & 24000 & - & - & - & $A R A B \|: 143$ \\
\hline
\end{tabular}

TU II, Tukulti-Urta II (890-884 BCE); ANP, Assur-Nâsir-Pal II (883-859 BCE); S III, Shalmaneser III (858-824 BCE); AN III, Adad-Nirari III (810-783 BCE); TP III, Tiglath-Pileser III (744-727 BCE); S II, Sargon II (721-705 BCE); SB, Sennacherib (704-681 BCE); EH, Esarhaddon (680-669 BCE).

$t$, In the annals, silver usually appears before gold.

\#. Nobles paid a punitive tribute for killing ruler Amma-ba'li. ANP placed his brother llânu on the throne and demanded further tribute (ARAB 1:181).

$\S$, The Kurkh Monolith lists 500 talents of copper. The Annals list 100 talents (ARAB I:181).

I, ARAB I:288 and summary inscription 7:16 'state 150 talents. Summary inscription 9:26' states 50 talents.

$\dagger$, Included several places conquered by Tiglath-Pileser III in 744 and 737 BCE (Tadmor 1994:164n).

1., Menahem of Israel rendered 1000 talents of silver, that is, the equivalent of $30000 \mathrm{~kg}$, but is not reflected in this table as no Assyrian reference has been found.

$\S \S$, Hazael was the king of the Arabs (ARAB II:207).

[Jehoahaz, ${ }^{7}$ king of Judah]. ${ }^{8}$ Based on the textual evidence, 33 years then elapsed before Judah was expected to render tribute again in 701 BCE. Archaeology, however, has provided evidence that this was not the case. At least three further payments were made:

- The Nimrud Letter ND 2765 records the receipt of horses by Marduk-remanni, the governor of Kalhu during the reign of Sargon II (Dalley 2004:388).

- A small tablet dating to the time of Sargon II or Sennacherib records the receipt of ten manus $^{9}$ (or minas [XI 33:5-6]) (Dubovský 2006:198) of silver from Judah (Mitchell 1988:56).

- 1 talent of silver (XI 57:1) (Dubovský 2006:198).

This additional information renders the fact that Judah, a tiny, landlocked country lacking natural resources and having an economy that could, at best, be categorised as a subsistence agrarian economy, was simultaneously able

7.Ahaz's full name as recorded on Tiglath-Pileser III's inscription (Pritchard 1969:282)

8.Tablet summary inscription 7-K3751 was probably found at Nimrud (Tadmor 1994:155, 171).

9.The Babylonian manus was the equivalent of $505 \mathrm{~g}$ (Mitchell 1988:56). to accumulate the quantities of silver and gold to meet the demands of Sennacherib in 701 BCE even more amazing. In addition, the authors of Chronicles make no bones about Hezekiah's enviable financial situation:

Hezekiah enjoyed immense riches and honour. He built himself treasuries for gold, silver, precious stones, spices, jewels and every kind of desirable object, as well as storehouses for his returns of grain, new wine and olive oil, and stalls for all kinds of cattle and pens for the flocks. He also provided himself with donkeys in addition to his immense wealth of flocks and herds, since God had made him immensely wealthy. (2 Chr 32:27-29)

\section{Possible sources of revenue}

If we take the biblical narratives (particularly in Chronicles) seriously, the question remains, how did the Judaean king acquire such wealth to meet Sennacherib's demands? Or, in other words, which ways did the Lord use 'to bless' Hezekiah as suggested by the biblical narrators? Based on the textual and archaeological evidence the following alternatives are put forward as Hezekiah's additional sources of revenue:

- international trade in exchange for exportable Judaean agricultural products 
- new industry

- a possible additional tax imposed on the men of Judah and

- income from the religious reforms and tolls and taxes imposed on the overland trade.

\section{The export of Judaean agricultural products}

Agriculture is generally believed to have formed the basis of the Judaean economy. In our opinion, however, the export of Judaean agricultural products could not account for the extent of Hezekiah's wealth, even if crop specialisation and intensified cultivation of cereals, grapes and olives took place during the Iron Age II, as some scholars claim basing their arguments on 2 Chronicles 26:10 (cf. Chaney 1993:253; Lowery 1991:37; De Geus 1982:56-57). They were insufficient in volume and value, and for the following reasons could not have constituted Hezekiah's only source of revenue:

- The high risk and dangers involved as well as prohibitive overland transportation costs due to bulk and weight (cf. Heichelheim 1965:244; Muth 2000:368). The cost of transporting grain farther than $20 \mathrm{~km}$ makes it financially unattractive. If grain is transported any farther its nett value exceeds its actual value in terms of saleability at a profit (Clark \& Haswell 1970:191).

- The economies of the surrounding Mediterranean countries were all largely pre-industrial, self-sufficient subsistence agrarian economies supported by the same crops (olives, grapes and cereals), which limited trading opportunities.

- The prohibitive biblical laws were responsible for the noncapitalist Judaean society. According to the Book of Joshua $(18: 3,19: 51)$, the land allocated each family when the tribes gathered before the door of the tabernacle in Shiloh was governed by a number of prescriptions. Ownership was inalienable and sale of the property outside the family or clan was restricted. These prescriptions were meant to prevent the buying and selling of land on speculation and was ultimately a means of preventing land monopoly.

- The rural farmers were already overburdened with substantial taxes and tithes imposed by political (Ex 30:13-14) and cultic authorities (Lv 27:30-33).

- There is limited archaeological evidence available to prove otherwise. Nothing similar to the olive oil production centre at Ekron or storage facilities similar to those built by King Solomon has been found. Hopkins (2000:1325) considers the general absence of areas in the Iron Age cities similar to the Greek agora, evidence that the exchange of surplus commodities took place on a small scale, with the bulk of produce consumed by the farmer's family or rendered as tax to the crown or as tithes to the Temple. It was in this form that the Judaean agriculture contributed to the Judaean economy.

\section{New industry}

For either agricultural or artisanal products to make a significant contribution to the economy, large-scale production supported by an efficient and intense distribution system over large distances would have been essential. Here again, supportive literary and archaeological evidence is lacking for both. The $L M L K$ jars $^{10}$ that appeared during Hezekiah's reign and the Judaean ceramic figurines suggest production on a larger and organised scale, but their appearance in the archaeological record is limited to the Judaean heartland (cf. Grena on the LMLK research website [cited 15 July 2009]; Mommsen, Perlman \& Yellin 1984:89; Kletter 2001:181-183).

\section{A tax on the 'men of Judah'}

According to 2 Kings 15:20 there is the possibility that Hezekiah, like Menahem of Israel, imposed a tax on the men of Judah to meet the tribute demands. Working with the same ratio, ${ }^{11}$ in other words one man to every 3.5 inhabitants and a population estimated at about 111500 , every Judaean male would have had to pay 86.5 shekels of silver to meet Sennacherib's demands, the equivalent of $920^{12}$ talents of silver. Many farmers would have been hard pushed to do so, especially considering the numerous civic and religious taxes and tithes already imposed on them.

It is highly unlikely that Hezekiah resorted to these measures. Not only is the 'Deuteronomist' silent on the subject, but judging from the biblical texts, the amounts of silver and gold were already available in the treasuries. It is possible, but there was no necessity to impose an additional tax on the people.

\section{Income from religious reforms}

Although the 'Deuteronomistic writing' and the Chronicler present two very different accounts of Hezekiah and his reign, in which religious concerns understandably take precedence over political concerns, both agree Hezekiah reformed the cult and centralised worship in Jerusalem (2 Ki 18:4; 2 Chr 31; Miller \& Hayes 1986:349).

\section{Centralising the cult in Jerusalem}

The Chronicler (2 Chr 29) states that by removing the high places Hezekiah appears to have centralised the cult and consolidated all worship at the Temple in Jerusalem. This reform had far-reaching results and consequences.

Three major feasts ${ }^{13}$ dominated the Israelite religious calendar: the Feast of the Unleavened Bread (7 days), the Feast of the Weeks (1 day; Rowley 1962:61-62, 395-431) and the Feast 10.Imlk (למלך) means '[belonging] to the king'.

11.One thousand talents is the equivalent of 3000000 shekels. Some 60000 men would have had to pay 50 shekels to meet these demands. The population of the Northern Kingdom was approximately 209750 in the late 8th century BCE (Broshi \& Finkelstein 1992:54). This would mean there was one man to every 3.5 people.

12.One talent of gold was the equivalent of four talents of silver and 30 talents of gold the equivalent of 120 talents of silver. Together with the 800 talents of silver, Sennacherib's demand in silver was either 420 or 920 talents.

13.It could have added value to the discussion of the biblical laws' consequences on the economic situation of Judah if the question of the contexts in which the concepts underlying biblical laws concerning land ownership or feast regulations originated could be investigated, but due to space constraints it will not be discussed here. 
of Ingathering (8 days; Coogan 2006:134-136; Ex 23:14-17). According to Deuteronomy, the law obliged all males to make tri-annual pilgrimages to appear before 'Yahweh your God' in the place chosen by Him for these feasts (Dt 16:1-17). Assumedly this generated considerable income for the local cult sites, staffed by priests who conducted the sacrifices (1 Ki 13:2; 2 Ki 17:11; Smith 2002:160). By authorising their removal, Hezekiah terminated their legal status and that of the cult personnel operating there. Tithes and taxes could no longer be conveniently delivered to the nearest local shrine. Taking into consideration the inconvenience of the journey and of tediously transporting the tithes to Jerusalem, Deuteronomy pragmatically allows for the tithes to be redeemed for silver (Dt 14:24-26; Stevens 2006:94).

\section{The archaeological remains}

Despite extensive archaeological excavations conducted throughout Palestine, very few cult sites have been discovered, only two of which have been dated to the Iron Age II period: the sanctuary at Arad (Stratum VIII) and the large dismantled sacrificial altar at Beersheba (Stratum II: Herzog, Aharoni, Rainey \& Moshkovitz 1984:19; Mazar 1992:496).

- The appearance of the Judaean weights ${ }^{14}$ for weighing precious metals (in this case silver) at the end of the late 8th century BCE might be an incidental consequence of this reform.

- The discovery of the domestic shrine at Tel Halif, the various anthropomorphic and zoomorphic figurines, Hezekiah's iconic seals, and the jars, ${ }^{15}$ all dating in the late 8th to early 7th century BCE, suggest that Hezekiah's reforms were not comprehensively iconoclastic, but limited to the eradication of the local shrines so as to centralise the cult at the Temple in Jerusalem. The ramifications of Hezekiah's reform programme suggest religious zeal was not the king's only motivating force. As mentioned above, political, economic, and strategic objectives appear to have played a significant role.

\section{Political reasons}

Obviously, Hezekiah was making full use of his rights as head of state to introduce changes to the practices, the festivals and the organisation of the cult (Ahlström 1982:65). The extent of the reforms also emphasised his position, authority and political power.

By removing the bāmôt (במות) [high places] Hezekiah appears to have centralised the worship at the Temple in Jerusalem,

14. Hundreds of limestone scale weights, inscribed as well as uninscribed, have been discovered in Judah. They date to both the late 8 th, but predominantly 7th century $\mathrm{BCE}$. The inscribed limestone weights are a specifically Judaean phenomenon, uniform in inscription, material (stone and metal), shape and weight, indicating one single system with one major standard. Of the 211 weights with known provenance, only six can be dated conclusively to the late 8th century BCE and 188 to the 8th to 7th centuries BCE (Seger 2000:90). The largest number of weights to the 8th to 7th centuries BCE (Seger 2000:90). The largest number of weights economy. Considerable numbers were found in the regional centres Lachish (25) and Arad (15) (Kletter 1999:32).

15. Handles bearing the Imlk (למלך) stamp and either a two-winged sun disk or a winged scarab belong to large Judaean storage jars and are believed to be a phenomenon of Hezekiah's reign in the late 8th to early 7th century BCE (Diringer 1949:72; Grena 2004:110) elevated the status of both the Temple and the capital city, increased and extended his own authority as Yahweh's earthly emissary, and undercut the power and influence of the priests at the local shrines throughout the country. This reform ultimately denied the cult personnel a means of livelihood, food and clothing, regulated in Exodus (23:19), Leviticus $(2: 14 ; 6: 26 ; 29 ; 7: 6-10 ; 26: 1-10 ; 27: 5)$, Numbers $(18: 8-19,26-28 ; 31: 25-47)$ and Deuteronomy (14:28; 26:12). Fully aware of the power and influence of the priests and Levites over their 'congregations', Hezekiah commanded the people to feed them (2 Chr 31:19). Borowski (1995:153) states that this directive would not only have prevented the cult personnel from being left destitute but would also have ensured their support for his reforms.

Herzog et al. (1984:21) are convinced that the cult centralisation was an attempt by Hezekiah to establish a bond to the national sanctuary and the royal city. Anticipating war with Assyria, this was an expedient move on his part, especially considering the significant number of refugees from the north living in Judah, who would not necessarily have developed the same nationalism as the Judaeans. Weinfeld (1964) points out that in 1922 Oestreicher ${ }^{16}$ already recognised the political undercurrent of Hezekiah's cultic reforms. In 1985 Gottwald supported the theory that Hezekiah's religious reforms were part of his nationalistic anti-Assyrian programme (Gottwald 1985:369). Coogan (2006:329), on the other hand, regards Hezekiah's invitation to the northern tribes to attend the Passover as a move to extend his royal control to the former Northern Kingdom.

\section{Economic reasons}

The considerable economic benefits to be gained as a result of these reforms would not have escaped Hezekiah. Although a national census taken during Hezekiah's reign (1 Chr 4:38ff.) was probably mainly for conscription purposes in preparation for war with Assyria, it would also have been taken with tax purposes in mind. Revenue from taxes would have helped finance Hezekiah's various building projects, ${ }^{17}$ equip the army and protect the trade routes. As Gottwald (1985:389) points out, Hezekiah's religious reforms certainly reflect a reorganisation of the tax system in Judah. Ostraca found at the temple-fortress at Arad list rations of flour, oil and wine that were to be distributed to itinerant military personnel. This suggests the temple officials were responsible for storing and distributing commodities (Mazar 1992:441).

The Chronicler is of the opinion that by centralising the cult at the Temple in Jerusalem, Hezekiah ordered all tithes and taxes to be sent directly to the capital city (2 Chr 31:10ff.). He thereby effectively streamlined the flow of funds to the capital and removed the middlemen in the chain of financial flow. This reduced the chances of funds being siphoned off by each person through whose hands they passed. The complicated sacrificial system, which had

16.Weinfeld (1964:202) refers to the book entitled Das deuteronomische Grundgeset [The Deuteronomic Code] by Th. Oestreicher (1923).

17.If they can be attributed to him. Please see footnote 4 above. 
in the past involved the redistribution of meat and grain, now came under royal control, along with the rest of the economy (Borowski 1995:153; Coogan 2006:328). The portion of the tithes designated for the priests and Levites would then be distributed from Jerusalem to the cities of Judah (2 Chr 31:14ff.; Ahlström 1982:67).

All major festivals were also to be celebrated in Jerusalem. To ensure the people journeyed to Jerusalem with their tithes, instead of delivering them to the cult personnel at the מצבת מצral shrines, Hezekiah ordered the destruction of the [mitzbot; altars] and the אשרים, [asheriem; wooden poles] the divine symbols of the cult, and invalidated the significance of the במות [bamot; high places].

With the long-established pilgrimage festivals now to be celebrated at Yahweh's altar in Jerusalem (2 Ki 18:22), thousands of pilgrims would have swarmed to Jerusalem in obedience to the law, and in order to prevent themselves from being cut off from the people ( $\mathrm{Nm} \mathrm{9:13).} \mathrm{The} \mathrm{influx}$ of pilgrims to the capital city at least three times a year for a minimum of 16 days would have had the beneficial side-effect of stimulating the domestic economy of Judah (Gottwald 1985:389).

The journeys to Jerusalem would have afforded the rural population opportunities to engage in commercial activities through barter or in exchange for silver (Small 1997:276). In addition to the obligatory days of feasting, the pilgrims were instructed to consume the tithes, ${ }^{18}$ that is the first fruits and the firstborn of the animals in Jerusalem, or - if the road was too long they were permitted to redeem their tithe for silver (in which case an additional fifth of the yield was to be added to the sum, as stated in Lv 27:31) and then use the silver to purchase in Jerusalem whatever they pleased and consume it at the Temple (cf. Dt 14:24-25). These reforms would certainly have benefited the economy, the capital and the Temple.

\section{Strategic reasons}

Strategic motives certainly underlie Hezekiah's reforms. By centralising the cult in Jerusalem, the bond between the people and the capital would have been strengthened and, with rebellion on the cards, hopefully heightened their resolve to loyally defend the royal city against the Assyrians (Miller \& Hayes 1986:299).

In addition, if divine images and financially valuable cultic paraphernalia were features of the high places, then Hezekiah, anticipating the Assyrian attack, ensured their safety and prevented them from falling into enemy hands by closing down the rural sanctuaries and removing them to the Temple in Jerusalem (Handy 1988:111-115).

By having the tithes and taxes delivered directly to Jerusalem, Hezekiah most probably secured food supplies for an eventual

18.Even though the tithes would have been consumed by the pilgrims, they would still have had to journey to Jerusalem where they would have spent money, or its equivalent, offered sacrifices, et cetera. siege and also raised money with which to purchase weapons and arms. The accumulation of all agricultural surpluses in the well-fortified capital ensured that an invading army would be denied access to badly needed sustenance. Judah was no newcomer to the scene as far as invading armies were concerned. Tiglath-Pileser III and Sargon II had only shortly before campaigned in the region (ARAB II: 3; Stern 2001:228; Tadmor 1966:88; Tadmor 1994:177). Hezekiah would have been well aware of the logistics required to feed and water an invading or besieging Assyrian army. It is no coincidence that Hezekiah assumedly had already secured Jerusalem's water source by constructing the Siloam Tunnel (2 Ki 20:20; Is 22:11; 2 Chr 32:2-4, 30), just as it is no coincidence that Sennacherib targeted Lachish instead of Jerusalem. Whilst water was essential to a besieged city, it was equally important to the besieging army, particularly if the army was stationed in the dry Judaean highlands. The Franks reported the following about Jerusalem (Fink 1969):

[T] he city of Jerusalem is located in a mountainous region which is devoid of trees, streams, and springs excepting only the Pool of Siloam, which is a bowshot from the city. Sometimes it has enough water, and sometimes a deficiency due to slight drainage. (p. 116)

According to 2 Kings 19:35 Sennacherib's army was at least 185000 men strong. If each soldier required 2.5-3 litres $^{19}$ water per day, then without even considering the cavalry horses, Sennacherib's soldiers would have required a minimum of 462500 litres of water per day. Following Engels (1978:57), who calculated that a Macedonian soldier using a 15-litre vessel could only remove about 87216 litres of water in 24 hours for Alexander's army, Sennacherib's army would have required five soldiers, or ten soldiers working 12 hours - if the water sources did not run out first. The absence of rivers in the vicinity of Jerusalem was a major deterrent to Sennacherib. Access to water might have been less of a problem in the Shephelah, with its numerous wadis and proAssyrian cities situated in the plain of Philistia not far off (Rainey 2000:1001).

\section{Tolls and customs duties levied on the international trade}

The tributes demanded by the Assyrians from Tyre and Damascus were substantially larger than the demands made on the other countries and kings (see Table 1). The sizes of the tributes reflect the cities' wealth and ability to meet their demands. Both cities lay at advantageous and important intersections of numerous international overland trade routes and are a clear indication of the financial benefits to be gained from maintaining control of the commercial activities in the region. The fact that the Assyrian monarchs were prepared to fight to gain or retain control of transit trade through the Levant, as well as the trade in the Mediterranean basin, provides substance to this claim.

Judah's role in the international market was limited by her lack of a major sea port and natural resources. Even though

19.It is universally recognised that a person requires a minimum of $2.5-4.5$ litres of water per day. See Gleick (1996:84). 
the two international trade routes, the King's Highway and the Via Maris, lay outside her boundaries (Kletter 1998:149), an extensive network of roads criss-crossed the country, providing Judah and Hezekiah with ample opportunity to benefit financially from the trade that passed through the region.

It was customary to impose taxes in the form of tolls, duties, and transit fees on the cargo at toll stations or in the towns through which the caravans passed on their way to their final destinations (Barrell 1998). Handsome customs and duties were also extracted for a safe passage through the country, for the watering of the camels, and the feeding of both the animals and people accompanying the caravans. This practice was common in the ancient Near East. The Assyrians usually imposed miksu [to take a share as taxes] on merchandise and agricultural products that crossed borders and passed through stations within Assyria proper and its provinces (Elat 1991:26; Postgate 1974:354-355). It is not unreasonable to conclude that Hezekiah did likewise - like his ancestor King Solomon had done before him. If Hezekiah had begun milking the trade that passed through the Eastern seaboard of the Mediterranean, as the textual evidence suggests, then Sennacherib would have had every reason to march against him and reassert Assyrian hegemony in the region.

\section{Conclusion}

Although Lowery (1991:130) maintains Judah's status as an Assyrian vassal 'drained the life of Judah', with a social crisis the inevitable outcome, this statement requires qualification. Judah's financial obligations to Assyria should have drained the life out of Judah, but they did not. Hezekiah was 'immensely wealthy' (2 Chr 32:27-29) and his country's storehouses, treasuries, and armoury were bulging. Judah, along with Mati'il of Arpad, paid the third largest amount of gold and the eighth largest amount of silver demanded by the Assyrians during this period. From the information contained in the table earlier in the text, it appears that the majority of the countries that rendered greater quantities of precious metal were situated at strategic locations to benefit from the trade passing through the area. Apparently, ' $[t]$ he siege of Jerusalem is part of a greater process of Assyrian politics aiming at the control over the road to Egypt' (Becking 2007:284).

Whilst the biblical writers present Hezekiah's reformation programme as motivated solely by piety and righteousness, the preceding discussion has shown that it ultimately benefited him sociopolitically, strategically and, more importantly, economically. It gave Hezekiah control of the entire Judaean economy and directed the flow of tithes and taxes to the Temple in the capital city (Borowski 1995:153). Perhaps these were the riches received from Yahweh to which the biblical writers referred in 2 Chronicles 32:27. Either way, they would definitely have constituted a major source of income for Hezekiah.

As mentioned above, Judah was economically extremely well situated. This was partially or completely thanks to the trade routes passing through the country. Socially, however, the outrage and accusations of the prophets suggest all was not as it should have been.

Obviously, there is no avoiding taking the elusiveness of the past into account when undertaking historical research (Derrida 1997:102-107). According to Le Roux, no method exists that can help alleviate the 'feeling of loss' emphasised by the traces of history (1998:458). ${ }^{20} \mathrm{He}$ adds (1998:458) that the 'historian [Old Testament scholar] can present us with his [/her] version of the past, but it will not provide the past itself, only the re-thinking of it' (insertions added). All history is therefore 'the re-enactment of past thought in the historian's own mind' (Collingwood 1994:215). In our opinion, the archaeological evidence provides a very different picture to the idealistic portrayal of the Israelite religion conveyed by the biblical texts and does add some value to our understanding. The instances where it can be shown that the biblical narratives and archaeology converge, suggest that traces of history, or a historical core, do exist in the Bible.

\section{Acknowledgements Competing interests}

The authors declare that they have no financial or personal relationship(s) that may have inappropriately influenced them in writing this article.

\section{Authors' contributions}

M.leR. (University of South Africa) was the supervisor and contributed substantially towards the compiling and finalising of the article. G.A.R. (University of South Africa) was a Magister student of M.leR.

\section{References}

Ahlström, G.W., 1982, Royal administration and national religion in ancient Palestine, Brill, Leiden.

Ahlström, G.W., 1991, 'The role of archaeology and literary remains in reconstructing Israel's history', Journal for the Study of the Old Testament, suppl. ser. 127 116-141.

Ankersmit, F.R., 1988, 'De Angelsaksische hermeneutiek en de geschiedbeoefening', in T. de Boer (ed.), Hermeneutiek, pp. 121-150, Boom, Amsterdam.

Barrell, E.A., 1998, 'A survey of the Old Assyrian Trade with Kaniš in the Middle Bronze Age', MA dissertation, University of Stellenbosch.

Bär, J., 1996, Der assyrische Tribut und seine Darstellung: Eine Untersuchung zur imperialen Ideologie im neuassyrischen Reich (AOAT 243), Neukirchener, Neukirchen Vluyn.

Becking, B., 2007, 'Sennacherib and Jerusalem: New perspectives', Journal for Semitics 16(2), 267-288.

Blakely, J.A. \& Hardin, J.W., 2002, 'Southwestern Judah in the late eighth century', Bulletin of the American Schools of Oriental Research 326, 11-64. http://dx.doi. org/10.2307/1357687

Borowski, O., 1995, 'Hezekiah's reforms and the revolt against Assyria', Bayesian Analysis 58, 148-155.

Broshi, M. \& Finkelstein, I., 1992, 'The population of Palestine in Iron Age II', Bulletin of the American Schools of Oriental Research 287, 47-60. http://dx.doi. org/10.2307/1357138

Buchholz, T.G., 1988, 'Biblical laws and the economic growth of ancient Israel', Journal of Law and Religion 6(2), 389-427. http://dx.doi.org/10.2307/1051157

Chaney, M.L., 1993, 'Bitter bounty: The dynamics of political economy critiqued by the eighth-century prophets', in N.K. Gottwald \& R.A. Horsley (eds.), The Bible and liberation: Political and social hermeneutics (rev. ed), pp. 250-263, Orbis, Maryknoll.

20.The knowledge of the past can be gained when the past is re-enacted in the mind of the historian (Ankersmit 1998:121-150; cf. Van der Dussen 1994:ix-xlviii). 
Clark, C. \& Haswell, M., 1970, The economics of subsistence agriculture, 4th edn., MacMillan, London.

Collingwood, R.G., 1994, The idea of history, University Press, Oxford.

Coogan, M.D., 2006, The Old Testament: A historical and literary introduction to the Hebrew Scriptures, Oxford University Press, Oxford.

Dalley, S., 2004, 'Recent evidence from Assyrian sources for Judaean history from Uzziah to Manasseh', Journal for the Study of the Old Testament 28(4), 387-401. http://dx.doi.org/10.1177/030908920402800401

De Geus, C.H.J., 1982, 'Die Gesellschaftskritik der Propheten und die Archäologie' [The social criticism of the prophets and the archeology], Zeitschrift des Deutschen social criticism of the proph
Palästina-Vereins $98,50-57$.

Derrida, J., 1997, Limited Inc, Northwestern University Press, Illinois.

Diringer, D., 1949, The royal jar-handle stamps of ancient Judah, BA 12(4), 70-86.

Dubovský, P., 2006, Hezekiah and the Assyrian spies: Reconstruction of the NeoAssyrian intelligence services and its significance for 2 Kings 18-19, Pontificio Instituto Biblico, Rome.

Elat, M., 1991, 'Phoenician overland trade within the Mesopotamian empires', in M. Cogan \& I. Eph'al (eds.), Ah, Assyria .... Studies in Assyrian history and ancient Near Eastern historiography presented to Hayim Tadmor, pp. 21-35, Magnes Press, Jerusalem.

Engels, D.W., 1978, Alexander the Great and the logistics of the Macedonia army, University of California Press, Berkeley.

Fink, H.S. (ed.), 1969, A history of the expedition to Jerusalem 1095-1127 by Foucher de Chartres [Fulcherius, Carnotensis], transl. Frances Rita Ryan, University of Tennessee Press, Knoxville.

Gleick, P.H., 1996, 'Basic water requirements for human activities: Meeting basic needs', International Water Resources Association 21, 83-92.

Gottwald, N.K, 1985, The Hebrew Bible: A socio-literary introduction, Fortress, Philadelphia.

Grabbe, L.L., 1997, 'Introduction', Journal for the Study of the Old Testament, suppl. ser. $245,11-18$

Grena, G.M., 2009, The LMLK research website, viewed 15 July 2009, from http:// www.Imlk.com

Grena, G.M., 2004, LMLK - a mystery belonging to the king, vol. 1, 4000 Years of Writing History, Redondo Beach.

Handy, L., 1988, 'Hezekiah's unlikely reform', Zeitschrift für Alttesamentalische Wissenschaft 100, 111-115.

Heichelheim, F.M., 1965, An ancient economic history from the Palaeolithic age to the migrations of the Germanic, Slavic, and Arabic nations, Revised ed. vol. I., transl. Joyce Stevens, Sijthoff, Leiden.

Herzog, Z., Aharoni, M., Rainey, A. \& Moshkovitz, S., 1984, 'The Israelite fortress at Arad', Bulletin of the American Schools of Oriental Research 254, 1-34. http:// dx.doi.org/10.2307/1357030

Holladay, J.S., 2006, 'Hezekiah's tribute, long-distance trade, and the wealth of nations ca. 1000-600 B.C.: A new perspective', in S. Gitin, W.J. Edward \& J.P. Dessel (eds.), Confronting the past: Archaeological and historical essays on ancient Israel in Confronting the past: Archaeological and historical essays on ancien
honor of William G. Dever, pp. 311-331, Eisenbrauns, Winona Lake.

Hopkins, D.C., 2000, 'Trade and commerce', in D.N. Freedman (ed.), Eerdmans dictionary of the Bible, pp. 1323-1225, Eerdmans, Michigan.

Jonker, L.C., 2007, 'Reforming history: The hermeneutical significance of the books of Chronicles', Vetus Testamentum 57(1), 21-44. http://dx.doi. org/10.1163/156853307X167846

Jonker, L.C, 2012, "What do the "good" and the "bad" kings have in common? Genre and terminological patterns in the Chronicler's royal narratives', Journal for Semitics 21(2), 340-373.

Kletter, R., 1998, 'Economic keystones: The weight system of the kingdom of Judah', Journal for the Study of the Old Testament, suppl. ser. 276.

Kletter, R., 1999, 'Pots and polities: Material remains of Late Iron Age Judah in relation to its political borders', Bulletin of the American Schools of Oriental Research 14, 19-54. http://dx.doi.org/10.2307/1357450
Kletter, R., 2001, 'Between archaeology and theology: The pillar figurines from Judah and the Asherah', Journal of the Study of the Old testament, supp. ser. 331 179-216.

Le Roux, J.H., 1998, 'Israel's past and the feeling of loss (Or: Deconstructing the "minimum" of the "minimalists" even further)', Journal of the Study of the Old Testament 11(3), 477-486.

Lowery, R.H., 1991, 'The reforming kings: Cults and society in First Temple Judah', Journal of the Study of the Old Testament, suppl. ser. 120 .

Luckenbill, D.D. (ed.), 1968, Ancient Records of Assyria and Babylonia (ARAB), Greenwood, New York.

Mazar, A., 1992, Archaeology of the land of the Bible, Doubleday, New York.

Miller, J.M. \& Hayes, J.H., 1986, A history of ancient Israel and Judah, Westminster, Philadelphia.

Mitchell, T.C., 1988, Biblical archaeology: Documents from the British Museum, Cambridge University Press, Cambridge.

Mitchell, C., 2007, 'Power, eros, and biblical genres', The Bible and Critical Theory 3(2), 18.1-18.11.

Mommsen, H., Perlman, I. \& Yellin, J., 1984, 'The provenience of the Imlk jars', Israel Exploration Journal 34(2-3), 89-113.

Muth, R.F., 2000, 'Economics', in D.N. Freedman (ed.), Eerdmans dictionary of the Bible, pp. 368-379, Eerdmans, Michigan.

Postgate, J.N., 1974, Taxation and conscription in the Assyrian Empire, Biblical Institute, Rome.

Pritchard, J.B. (ed.), 1969, Ancient Near Eastern texts relating to the Old Testament (ANET), University Press, Princeton.

Rainey, A.F., 2000, 'Land of Palestine', in D.N. Freedman (ed.), Eerdmans dictionary of the Bible, pp. 998-1004, Eerdmans, Michigan.

Röthlin, G.A., 2009, 'Gold and silver for a kingdom. The Judaean economy in the Iron Age II: Possible sources for King Hezekiah's wealth', Unpublished MA dissertation, University of South Africa.

Rowley, H.H., 1962, 'Hezekiah's reforms and rebellion', Bulletin of the John Ryland Library 44(61-62), 395-431.

Seger, J., 2000, 'Economic keystones: The weight system of the kingdom of Judah', Bulletin of the American Achools of Oriental Research 317, 90.

Small, D.B., 1997, 'Group identification and ethnicity in the construction of the early State of Israel: From the outside looking in', Journal for the Study of the Old Testament, suppl. ser. 237, 271-288.

Smith, M., 2002, The early history of God: Yahweh and the other deities in ancient Israel, 2nd edn., Eerdmans, Grand Rapids.

Stern, E., 2001, Archaeology of the land of the Bible: The Assyrian, Babylonian, and Persion periods (732-332 B.C.E.), vol. II, Doubleday, New York.

Stevens, M.E., 2006, Temples, tithes and taxes: The temple and the economic life of ancient Israel, Hendrickson, Peabody.

Tadmor, H., 1966, 'Philistia under Assyrian rule', Biblical Archeologist 29(3), 88. http:// dx.doi.org/10.2307/3211004

Tadmor, H., 1994, The inscriptions of Tiglath-Pileser III, king of Assyria, Israel Academy of Sciences and Humanities, Jerusalem.

Van de Mieroop, M., 2007, A history of the ancient Near East ca. 3000-323 BC, 2nd edn., Blackwell, Melden.

Van der Dussen, J., 1994, 'Editor's introduction', in R.G. Collingwood (ed.), The idea of history, pp. ix-xlviii, University Press, Oxford.

Weinfeld, M., 1964, 'Cult centralization in Israel in the light of a Neo-Babylonian analogy', Journal of Near Eastern Studies 23(3), 202. http://dx.doi. org/10.1086/371773

Wiseman, D.J., 1993, 1 and 2 Kings: An introduction and commentary, Inter-Varsity Press, Leicester. 